Article

\title{
A GIS Software Module for Environmental Impact Assessment of the Open Pit Mining Projects for Small Mining Operators in Kazakhstan
}

\author{
Mikhail Zarubin ${ }^{1}$, Larissa Statsenko ${ }^{2}$, Pavel Spiridonov ${ }^{3, * \mathbb{D}}$, Venera Zarubina ${ }^{1}$, Noune Melkoumian ${ }^{4}$ \\ and Olga Salykova 5
}

1 System Concepts And Applications, International Informatization Academy, Almaty 050000, Kazakhstan; zarubin_mu@mail.ru (M.Z.); zarubina_v@mail.ru (V.Z.)

2 STEM Department, University of South Australia, Adelaide 5005, Australia; larissa.statsenko@unisa.edu.au 3 InnovEco Australia, Adelaide 5008, Australia

4 School of Civil, Environmental and Mining Engineering, University of Adelaide, Adelaide 5005, Australia; noune.melkoumian@adelaide.edu.au

5 School of Information Systems, A.Baitursynov Kostanay Regional University, Kostanay 110000, Kazakhstan; solga0603@mail.ru

* Correspondence: p_spiridonov@hotmail.com

check for

updates

Citation: Zarubin, M.; Statsenko, L.; Spiridonov, P.; Zarubina, V.;

Melkoumian, N.; Salykova, O. A GIS

Software Module for Environmental Impact Assessment of the Open Pit Mining Projects for Small Mining Operators in Kazakhstan.

Sustainability 2021, 13, 6971.

https://doi.org/10.3390/su13126971

Academic Editor: Glen Corder

Received: 28 May 2021

Accepted: 17 June 2021

Published: 21 June 2021

Publisher's Note: MDPI stays neutral with regard to jurisdictional claims in published maps and institutional affiliations.

Copyright: (c) 2021 by the authors. Licensee MDPI, Basel, Switzerland. This article is an open access article distributed under the terms and conditions of the Creative Commons Attribution (CC BY) license (https:// creativecommons.org/licenses/by/ $4.0 /)$.
Abstract: This research article presents a software module for the environmental impact assessment (EIA) of open pit mines. The EIA software module has been developed based on the comprehensive examination of both country-specific (namely, Kazakhstan) and current international regulatory frameworks, legislation and EIA methodologies. EIA frameworks and methods have been critically evaluated, and mathematical models have been developed and implemented in the GIS software module '3D Quarry'. The proposed methodology and software module allows for optimised EIA calculations of open pit mines, aiming to minimise the negative impacts on the environment. The study presents an original methodology laid out as a basis for a software module for environmental impact assessment on atmosphere, water basins, soil and subsoil, tailored to the context of mining operations in Kazakhstan. The proposed software module offers an alternative to commercial offthe-shelf software packages currently used in the mining industry and is suitable for small mining operators in post-Soviet countries. It is anticipated that applications of the proposed software module will enable the transition to sustainable development in the Kazakh mining industry.

Keywords: mining project; open pit mining; environmental impact assessment; EIA; geographic information system; GIS; pollution minimisation

\section{Introduction}

Sustainable development of mining regions is often a challenge, since mining operations are one of the largest sources of environment pollution and $\mathrm{CO}_{2}$ emissions [1]. Open pit mines create environmental risks, including the pollution of the atmosphere, noise exposure, contamination of surface and ground waters, impacts on biodiversity due to natural land transformation and loss of habitat, as well as community and cultural impacts, such as displacement of livelihoods and economic effects [2-4].

Mining companies are increasingly scrutinised by legislative and industry standards to minimise the negative impact on the environment by adhering to the tenets of environmental impact assessment (EIA) frameworks. EIA is usually undertaken at the initiation of the mining project and business case submission to relevant authorities. It outlines the anticipated scale of environmental impact and lays out initiatives for reducing and addressing negative impacts and achieving rational use of natural resources. Acceptance of the EIA report or Environmental Impact Statement (EIS) is one of the necessary conditions for the government to authorise exploration and mine design activities and for the mining 
company to obtain a social license to operate [5]. To get a social license to operate, mining companies have demonstrate measures taken to minimise negative impacts and risks and show contribution to the local economic and community development $[6,7]$. Therefore, EIA plays an important part in quantitative evaluation of the sustainability of mining projects and operations [8]. Key aspects for the EIA evaluation include the negative impacts of the considered mining activity on the environment, such as pollution of atmospheric air, surface and underground water, soil and subsoil [9].

In Kazakhstan, the mineral exploration activities are currently expanding [10], which puts the environmental protection at the forefront of the country's agenda. One of the key strategic priorities for the country is the implementation of an effective and responsible state environmental policy that aligns with the global sustainable development goals and national economic priorities [11]. For efficient EIA reporting across the country, reliable and timely information is required. Therefore, automation of the EIA calculations is of utmost strategic importance [12,13].

Previous research literature discussed EIA methodologies and frameworks pertaining to the country-specific legislative frameworks and best industry practices [14,15]. A number of models evaluated the impact on the atmosphere, water basins [16], soil and subsoil $[3,17]$. A number of EIA frameworks have been proposed by scholars in a variety of geographical and mining operation contexts $[18,19]$. The literature also identifies gaps and inefficiencies of the EIA frameworks, particularly in developing countries, discussing challenges and barriers for sustainable mine design, operation and closure $[18,20]$. However, there is limited research that offers models for small mining operators to meet the requirements of regulatory compliance for EIA reporting.

This research paper presents the results of the software module development for automated calculations of the EIA parameters and EIA reporting, which is tailored to the needs of small open pit mining operators. An extensive review of the current literature, legislative and regulatory documents enabled the proposal of a methodological framework as a basis for the software module development. This paper provides a case study of the EIA parameter calculations using the proposed EIA software module within the integrated GIS ‘3D Quarry’ system.

\section{Theoretical Background}

\subsection{Methodologies for the Environmental Impact Assessment (EIA) for Open Pit Mines}

An environmental impact assessment (EIA) is a legally binding procedure for the mining companies to comply with that requires evaluating the environmental impacts of a mining project on the environment [1]. The EIA tools vary depending on the type of mineral and mining technology, usually involving identification, assessment and reporting of environmental impacts and developing mitigation measures.

Environmental impacts and risks are quantified based on specific indicators used to characterise the environmental quality [19]. These indicators and their acceptable norms vary depending on the country's legislative frameworks, and international standards and regulations. For open pit mining of mineral deposits, the environmental impacts and risks include but are not limited to pollution of the atmosphere by emissions of gaseous and suspended substances, noise exposure, contamination of surface and ground waters, changes in hydro geological conditions, sewage and waste, impacts on biodiversity, flora and fauna, natural land transformation and loss of habitat, and community and cultural impacts, such as displacement of livelihoods and economic effects [2-4].

A range of methodologies and frameworks for EIA analysis are available, pertaining to the specificity of local legislative frameworks and best industry practices of environmental compliance. Among operation sustainability reporting frameworks, the most well-known is the Global Reporting Initiative (GRI) [21]. GRI includes mining and extractive sectorspecific indicators. However, the effectiveness of the GRI reporting system has been criticized for covering unsustainable actions at the mining site level [22]. 
The life cycle assessment (LCA) framework [23] is a holistic approach that considers all potential environmental impacts generated by organisational activity, including mine sites $[14,15]$. LCA has been applied to evaluate the EIA of the mining industry production processes, mining and mineral processing sector $[14,15,24]$.

An integrated EIA approach to the Rosia Montana mining site in the northwest of Romania was described in [19]. Researchers [18] focusing on the mine design and plan phase discussed the challenges of Polish mines to meet the targets of sustainable development. Salom and Kivinen [20], conducting EIA, identified challenges and barriers for sustainable mine closures drawing on the case from Namibia.

Lyu [16] developed an analytical approach for EIA of mining activities on groundwater, drawing on a case study of a copper mine in Jiangxi Province, China. Rahimi and Ghasemzadeh [17] and Rashidinejad et al. [3] offered models for calculating optimum cut-off grades that incorporated EIA parameters to minimise the environmental impact while optimising economical aspects to achieve maximum resource value. BojórquezTapia et al. [25] offered an approach based upon mathematical matrices to determine the significance of environmental impacts in the mining industry.

In post-Soviet countries, including Kazakhstan, the EIA methodologies that largely inform current regulatory and legislative frameworks are based on methods and technologies for managing dust and gas pollution of the atmosphere that were established in the fundamental works of Rzhevsky [26], Trubetskoy [27,28], Chanturiya [29] and others.

The issues of wastewater treatment and rational use of water resources at industrial enterprises are considered in the works of Ilyin V.I. [30], Gogina E.S. [31], Pavlova I.V. [32], Lesin Yu.V. [33,34], and Tyulenev M.A. [35].

\subsection{The Normative Frameworks for Mining Industry EIA}

One of the first environmental laws-The National Environmental Policy Act (NEPA) — was enacted in the United States on 1 January 1970 [36]. This environmental law promotes the enhancement of the environment and established the President's Council on Environmental Quality (CEQ). Legal and environmental authorities in each state of the United States developed their own legislation based on NEPA for the implementation of the EIA procedures. More than 100 nations around the world have been using NEPA as a guide to develop their national environmental policies [37].

In the European Union, legislative initiatives to protect the environment are based on the UN Directive 85/337/EEC for member countries of the European Economic Community (EEC) 'On the environmental impact assessment of selected public and private projects' [38]. Based on this document, the EU countries and Japan have developed their own legislative acts [39]. The regulation is carried out by the EU Eco-Management and Audit Scheme (EMAS). EMAS is a premium management instrument developed by the European Commission for companies and other organisations to evaluate, report, and improve their environmental performance [40].

The main international instrument is the United Nations Economic Commission for Europe's Convention on Environmental Impact Assessment in a Transboundary Context [41]. The main provisions of these documents are presented in the form of international standards in the field of environmental activities of the ISO 14000 series. The requirements for the environmental management system are established by the international standard ISO 14001: 2016 [42].

Environmental legislation in Australia is presented at Federal and State levels. The National Environment Protection Council Act 1994 [43] defines National Environment Protection Measures (NEPMs), which are a broad framework setting statutory instruments and outlining agreed national objectives for protecting or managing particular aspects of the environment.

At the state level, the Environment Protection Act 1993 [44], for example, provides the regulatory framework to protect South Australia's environment, including land, air and water. The environment protection activities in the state are administered by the 
Environment Protection Authority. The South Australia Mining Act [45] regulates and controls mining licensing, operations and other activities.

Legislative regulation of open pit mining in the Republic of Kazakhstan is based on the Constitution and is regulated by the following Codes: (1) The Code 'On Subsoil and Subsoil Use' dated 5 January 2021 [46]; (2) The Environmental Code dated 2 January 2021 [47]; (3) The Land Code dated 20 June 2003 [48]; and (4) The Water Code dated 9 July 2003 [49].

If an international treaty ratified by the Republic of Kazakhstan establishes rules different from those contained in the Codes, then the rules of the international treaty are applied.

The ISO 14000 standards in Kazakhstan operate on a voluntary basis. For these purposes, mining companies' environmental management systems must comply with the Kazakhstan Standard ST RK ISO 14001-2016. The certification is aimed at reducing the risk of emergency situations; minimisation of the negative impact of the organisation's activities on the environment; saving natural resources through their more rational use; reducing industrial and mining waste; improving the efficiency of internal management by systematising and documenting organisational procedures related to the environmental protection.

The ISO 14001-2016 standard in the Republic of Kazakhstan [50] is seen as the industry best practice, while the European Union Environmental Management and Auditing Scheme (EMAS) standard is imposed by government regulations. Both ST RK ISO 14001-2016 and EMAS are voluntary. According to the ST RK ISO 14001-2016 standard the certification is required every three years, while according to the EMAS standard the re-certification is not required. An audit according to the EMAS is carried out yearly or every two to three years. Inspection control of the compliance of the environmental management certificate to the ST RK ISO 14001-2016 is carried out once a year [51].

In the EIA procedure in the Republic of Kazakhstan and the EU, there are both significant similarities (in particular, regarding public participation) and significant differences (for example, in the stages of the EIA process) [52]. Table 1 demonstrates the comparison of the International and Kazakhstan environmental legislation procedures.

Table 1. Comparison of the International and Kazakhstan environmental legislation procedures.

\begin{tabular}{|c|c|c|}
\hline Comparison Parameter & International & Kazakhstan \\
\hline $\begin{array}{l}\text { Legal and regulatory } \\
\text { framework }\end{array}$ & $\begin{array}{l}\text { Directive 85/337/EEC, which began in } \\
\text { July 1998, } \\
\text { Directive 2011/92/EC5, UN/ECE Convention } \\
\text { (Aarhus Convention), signed in } 1998 .\end{array}$ & $\begin{array}{l}\text { Code 'On Mineral Resources and Their Use', dated } 5 \\
\text { January } 2021 \\
\text { Environmental Code, dated } 1 \text { February 2021; } \\
\text { Land Code, dated } 20 \text { June 2003; } \\
\text { Water Code, dated } 9 \text { July } 2003\end{array}$ \\
\hline Assessment objects & $\begin{array}{l}\text { Listed in EU Directive } 85 / 337 \text {, however the EU } \\
\text { members can determine which projects will be } \\
\text { subject to evaluation. }\end{array}$ & $\begin{array}{l}\text { The legislation establishes the principle of } \\
\text { compulsory state environmental expertise. }\end{array}$ \\
\hline $\begin{array}{l}\text { Stages of EIA } \\
\text { implementation }\end{array}$ & $\begin{array}{l}\text { Screening } \\
\text { Scoping } \\
\text { Preparation of the draft EIA } \\
\text { Preparation of the final document } \\
\text { Monitoring }\end{array}$ & $\begin{array}{l}\text { Notification of authorities, preliminary assessment, } \\
\text { terms of reference for conducting an EIA. } \\
\text { Investigation to assess the impact on the } \\
\text { environment, preparation of a preliminary version of } \\
\text { documents for EIA. } \\
\text { Preparation of the final version of documents on } \\
\text { environmental impact assessment. }\end{array}$ \\
\hline Public participation & $\begin{array}{l}\text { Mandatory informing the public, including } \\
\text { consultations with stakeholders and arranging } \\
\text { public meetings and hearings. }\end{array}$ & $\begin{array}{l}\text { Informing the public through publication in official } \\
\text { media, which indicates all the necessary information, } \\
\text { in particular the name, the purpose of the planned } \\
\text { activity, approximate timing and intended form of } \\
\text { public discussion (poll, hearings, referendum, etc.). }\end{array}$ \\
\hline Assessor & $\begin{array}{l}\text { Project developer with the involvement of } \\
\text { environmental consultants }\end{array}$ & Customer (performer)—an individual orlegal entity \\
\hline
\end{tabular}


Therefore, the EIA methods and technologies used in Western countries and the Republic of Kazakhstan, although different, require compliance to the mandatory legal requirements of the country and international standards at the voluntary discretion of the mining enterprise. Although there is a plethora of studies dedicated to the EIA in Western countries, much less has been known about the under-researched context of the post-Soviet environment, where EIA methodologies and regulations have been stemming from Soviet environmental science.

The next section looks at the aspect of EIA as a part of mine design and planning, as well as production control systems, outlining the current state of software available for mining enterprises to meet EIA requirements.

\subsection{Geographic Information Systems (GIS) and Software for EIA}

Minimising environmental impacts of an open pit mine can be achieved through the effective mine design and planning process. The complexity of these processes has increased over the last decades with increased reliance on the specialised software to set up mine parameters that meet the requirements for sustainable mining operations.

Currently the software packages used for mine design, planning and production control often contain advanced tools for 3-dimensional geometric modelling and visualisation, such as geographic information systems (GIS). The GIS-based software is used for both mine project planning and mining operation, including the assessment of mining-induced hazards [12,13].

According to one of the market leaders ESRI [53], the GISs equipped with a global positioning system (GPS) include many activities starting from mineral exploration through to mine planning and operation. As scholars claim [18], the market leading commercial software, including DataMine, GEOVIA Surpac package, MineScape by ABB's Intelligent Mining Solutions, or Maptek's Vulcan, offer solutions for planning, management and optimisation of mining projects and operations across the entire mining value chain, starting from exploration geology, geostatistics, modeling of deposits, planning, economic analysis and life-of-mine optimisation that involves minimisation of environmental impact. Mine planning and development software packages, such as ArcGIS Pro, GeoSoft, Vulcan, MineSight, SURPAC Range, or Mining Visualization System (MVS), can also be used to integrate recent survey data with block models or mine design data from other software.

A higher level of production control is achieved by integrating GIS/GPS systems with hardware and Internet of Things (IoT) devices used to control production in near real-time. Mining equipment, including mining vehicles, excavators and drilling rigs, become part of the integrated control system. One of the largest mining equipment manufacturers, Caterpillar, actively utilises GPS in machine control systems [54,55]. It has integrated autonomous trucks and drilling rigs into comprehensive open pit and underground mines automation technologies by using MineStar Edge platform [56].

The GIS and GPS integrated platforms are being widely applied for modelling mininginduced hazards and their environmental impact assessment and control. These applications include but are not limited to mine planning, operation, and environmental management [12]; deforestation assessment and forest reclamation procedures in mining; soil contamination and water pollution mappings in mining areas [13]; air pollution dispersion [4]; landslide susceptibility assessment [57]; and groundwater well potential mapping [58].

The current literature review shows that there is a limited research focused on developing GIS for EIA for open pit mines. Most available commercial solutions are integrated into mine planning and scheduling software, e.g., DataMine, Surpac and ArcGIS. The current research addresses this gap by developing an EIA framework for small open pit mines to efficiently design, plan, track and report EIA performance based on the best practice methodologies and the EIA standards tailored to the specific context of the Republic of Kazakhstan.

The first step in developing a software module for environmental impact assessment (EIA) was the critical evaluation of the existing methods for EIA and preventive measures 
related to atmosphere, water basin, land and subsurface for the open pit mines. This informed the development of a system architecture and a software module for open pit mines' EIA to meet Kazakhstan's laws and regulations.

\section{Methodology}

Since environmental impacts of open pit mines on the surrounding ecosystems are strictly regulated by both local legislation and international standards, a thorough analysis of the laws and regulations in Kazakhstan was conducted to identify critical parameters and values to be captured in the proposed software architecture solution. Environmental impact assessment was developed based on the analysis process which provided sufficient information for decision making [59].

Key environmental impacts of open pit mines (See Table 2) include impacts on water and air basins, earth and subsoil, and also flora, fauna, human health and recreational areas. The focus of this research is on the impact mining projects have on water and air basins, earth and subsoil.

Table 2. Key types and results of the impact of open pit mines on the environment.

\begin{tabular}{|c|c|c|}
\hline Elements of the Biosphere & Impact on the Elements of the Biosphere & Impact Result \\
\hline $\begin{array}{l}\text { Water: } \\
\text {-ground water }\end{array}$ & $\begin{array}{l}\text { Field drainage, discharge of waste and } \\
\text { drainage water }\end{array}$ & $\begin{array}{l}\text { Reduction of underground, ground and surface } \\
\text { water reserves. Violation of the hydrogeological } \\
\text { and hydrological regimes of the water basin }\end{array}$ \\
\hline $\begin{array}{l}\text { Water: } \\
\text {-surface water }\end{array}$ & $\begin{array}{l}\text { Drainage and transfer of surface reservoirs and } \\
\text { watercourses, discharge of waste and drainage } \\
\text { water, water intake for technical and } \\
\text { household needs of enterprises }\end{array}$ & $\begin{array}{l}\text { Pollution of the water basin by sewage and } \\
\text { drainage waters. Deterioration of water quality } \\
\text { as a result of adverse changes in hydrochemical } \\
\text { and biological regimes of surface and } \\
\text { underground waters }\end{array}$ \\
\hline Air & $\begin{array}{l}\text { Organised and unorganised emissions of dust } \\
\text { and gases into the atmosphere }\end{array}$ & Contamination (dust and gas contamination) day \\
\hline Land and soil & $\begin{array}{l}\text { Mining operations, construction of dumps, } \\
\text { hydraulic dumps, tailings and reservoirs. } \\
\text { Construction of industrial and civil buildings } \\
\text { and structures. Laying of roads and other } \\
\text { types of communications }\end{array}$ & $\begin{array}{l}\text { Deformation of the earth's surface. Violation of } \\
\text { the soil cover. Reducing the area of productive } \\
\text { land. Deterioration of soil quality. Changing the } \\
\text { appearance of the territory. Changes in the state } \\
\text { of ground and surface waters. Deposition of dust } \\
\text { and chemical compounds due to emissions into } \\
\text { the atmosphere. Erosion }\end{array}$ \\
\hline Subsoil & $\begin{array}{l}\text { Conducting mining operations. Extraction of } \\
\text { minerals host and overburdened rocks. The } \\
\text { drainage fields. Flooding of the field areas. } \\
\text { Ignition of minerals and waste rocks. Disposal } \\
\text { of harmful substances and industrial waste. } \\
\text { The discharge of wastewater }\end{array}$ & $\begin{array}{l}\text { Changes in the stress-strain state of a rock mass. } \\
\text { Reduction in the quality of minerals and the } \\
\text { industrial value of deposits. Pollution of the } \\
\text { subsoil. Development of karst processes. Mineral } \\
\text { losses due to dilution }\end{array}$ \\
\hline
\end{tabular}

As a measure of preventing the occurrence of an emergency in the open pit mine (e.g., spill of gasoline from the gas tank of vehicles and machinery), it is recommended to carry out technical inspection of vehicles before leaving the site and conduct timely repairs and replacement of spent consumables (oil, filters, etc.), damaged and worn-out parts and components of equipment.

\subsection{EIA Regulatory Frameworks in Kazakhstan}

\subsubsection{Atmosphere}

Assessment of the qualitative and quantitative composition of the expected harmful emissions to the atmosphere from open pit mines was carried out in accordance with the current regulatory and technical documents of the Republic of Kazakhstan [59]. 
To reduce the negative impact on atmospheric air, all measures can be divided into three groups: (1) replacing existing technology and equipment with more environmentally friendly ones; (2) equipping and retrofitting technological equipment with gas cleaning plants; and (3) more efficient use of the scattering capacity of the atmosphere.

To reduce the negative impact on the atmospheric air during mining operations, it is necessary that the following activities are performed regularly: (1) moistening dirt roads, mining ledges and dumps in the dry and hot season; (2) carrying out refuelling and maintenance of mobile equipment at the nearest gas station, or at a slightly remote private base with a hard surface; (3) monitoring the compliance of vehicle exhaust emissions before leaving the construction site in accordance with the established technical standards; and (4) collecting and temporarily storing waste in specialised containers and containers with subsequent transfer specialised third party service providers to process, neutralise or dispose of solid household waste (SHW) to landfills [59].

The size of the established sanitary protection zone (SPZ) can be reduced by minimising the content of harmful substances in the atmospheric air to an acceptable level as a result of environmental protection measures.

\subsubsection{Water: Surface and Groundwater}

The open pit mine design located near a water body has to comply with the conditions of the regime of water protection zones of watercourses and the Water Code of the Republic of Kazakhstan [49].

Environmental protection of surface waters includes the following measures: (1) mandatory collapse of the zone of the side ledge, which is the border of the coastal protective strip of the considered watercourse, which prevents surface runoff from the open pit mine; (2) compliance when working in the water protection zone of the nearest watercourse; (3) surface water monitoring, aimed at controlling the pollution of the watercourse during the transportation and haulage within the sanitary protection zone; (4) a rational water use regime that allows the use of imported water only for drinking needs and the intake of river water for irrigation of dirt roads only in dry and windy weather; (5) timely distribution of rainwater accumulated in the lower segments of the open pit mine over the entire overburden storage area; and (6) implementation of refuelling of open pit mine transport at specially equipped sites by vehicles at the nearest organised gas station.

Environmental protection measures of the groundwater reserves include: (1) carrying out mining operations to the full depth of extraction of raw materials only during the low-water period; (2) storage of special equipment on the inner-pit areas with a hard surface, located above the sole of the processing of open pit mine stocks by $0.5-1 \mathrm{~m}$; (3) implementation of refuelling of road equipment by a gas station attendant outside the open pit mine area with mobile vehicles at public gas stations; (4) exclusion of the collection and accumulation of production waste on the territory of the open pit mining site; (5) installation of a bio-toilet with timely removal to the nearest existing treatment facilities; (6) implementation of repair and maintenance of motor vehicles in specialised organisations; (7) water intake from the flooded part of the underground water of the open pit mine by the pump of the irrigation washing machine in a limited volume and only in the windy and hot season; (8) development of a monitoring system for open water bodies and aquifers; and (9) implementation of measures for the reclamation of the developed open pit mine areas in accordance with their subsequent use.

\subsubsection{Soil and Subsoil}

To reduce negative impacts on the soil, waste generated by the mine production has to be temporarily accumulated in metal containers on a specially designated area with a hard surface, followed by export to organizations that have licenses for its storage and disposal.

The land disturbed during mining operations should be reclaimed for subsequent use. Regardless of the usage, it is necessary to recultivate the adjacent territory, including 
land for temporary use for auxiliary facilities, storage sites for overburden dumps and the placement of a shift camp.

Overburden removal operations are carried out without first removing the soil layer due to low humus content and high salinity. In the future, the lithostrat of existing dumps can be used as a potentially fertile layer during the biological stage of recultivation and greening of overburden dumps.

The main requirements for the rational use and protection of subsoil and mineral resources are: (1) strict compliance with mine design decisions; (2) maintaining the geological survey documentation; (3) ensuring the complete extraction of raw materials; (4) reliable accounting of the reserves extracted and left in the subsurface, and producing mining plans and schedules; (5) protection of mineral deposits from flooding, fires and other factors that reduce the quality of minerals and the industrial value of deposits or complicate their extraction; (6) avoiding excessive losses, dilution and selective mining of minerals; (7) compliance with the requirements for the safe conduct of mining operations related to the use of subsurface resources; (8) conducting blasting operations below the level of underground water in a clamped environment, or extraction of minerals by the non-explosive method; (9) prevention of subsurface pollution by industrial waste or waste water.

These guidelines informed the selection of parameters to develop the EIA software module back-end and front-end architecture.

\subsection{Mathematical Models for EIA Module Assessment}

\subsubsection{Estimation of Harmful Emissions into Atmosphere for Open Pit Mining}

The estimation of the open pit mine impact on the atmosphere is determined by a comprehensive calculation of gross emissions of harmful substances from the drilling operations, blasting operations, rock loading and unloading, and the transportation of rock mass, transfer points and dumps. The methodology and formulas for these calculations are given in $[59,60]$.

Calculation of gross emissions of harmful substances during drilling operations is determined by the mass of dust emitted during blast hole drilling.

The dust mass $m_{d m}$ emitted during blast hole drilling can be determined by the following formula:

$$
m_{d m}=\sum_{i=1}^{n} Q_{v p i} \times q_{i} \times T_{i} \times K_{2} \times 10^{-3},
$$

where $Q_{v p}$ is the volumetric productivity of the $i$-th rig for drilling out the rock from the blast hole, $\mathrm{m}^{3} / \mathrm{h}$;

$q_{i}$-specific dust emission from $1 \mathrm{~m}^{3}$ of drilled rock with the $i$-th machine tool, $\mathrm{kg} / \mathrm{m}^{3}$;

$T_{i}$-annual net operating time of the drilling rig, $\mathrm{h} /$ year;

$n$-the total number of working machines in the section;

$K_{2}$-coefficient that considers the moisture content of the material.

The calculation of gross emissions of harmful substances during blasting operations is determined by the mass of harmful substances released during explosions during the year.

The mass of harmful gases $m_{g 1}$ (carbon monoxide, nitrogen oxides) emitted with a dust and gas cloud (DGC) is determined by the following formula:

$$
m_{g 1}=\sum_{i=1}^{2} q_{g s c i} \times K \times A \times 10^{-6},
$$

where $K$ is the conversion factor depending on the harmful gas to be determined (for example, for carbon monoxide $\mathrm{CO} K=1.25 \mathrm{~g} / \mathrm{L}$, for $\mathrm{NO}_{\mathrm{x}} \mathrm{K}=1.4 \mathrm{~g} / \mathrm{L}$ );

$q_{g s c}$ - the specific content of harmful gases in DGC formed during the explosion of $1 \mathrm{~kg}$ of explosives, $\mathrm{L} / \mathrm{kg}$;

$A$ - the quantity of blasted explosives, $\mathrm{kg}$. 
The mass of harmful gases $m_{g 2}$ remaining in the blasted rock mass (RM) and gradually released into the atmosphere is calculated by the following formula:

$$
m_{g 2}=\sum_{i=1}^{2} C_{g c i} \times Q_{r m} \times 10^{-9},
$$

where $C_{g c i}$ is the concentration of harmful gases in the blasted rock mass, $\mathrm{mg} / \mathrm{m}^{3}$;

$Q_{r m}$ - the volume of the blasted rock mass, $\mathrm{m}^{3}$.

The formula for calculating the concentration of harmful gases in the blasted rock mass is as follows:

$$
C_{g c i}=\frac{q_{g r i} \times K \times A \times 10^{3}}{Q_{r m}\left(K_{p}-1\right)},
$$

where $q_{g r i}$ is the specific content of harmful gases in the blasted rock mass (RM), depending on the hardness of the rocks and the explosive formulation, $\mathrm{L} / \mathrm{kg}$;

$K_{p}$-the coefficient of the rock mass fragmentation.

The total mass $M_{g}$ of hazardous gases released during the blast is determined by the Formula (4) (expressed as carbon oxide CO):

$$
M_{g}=m_{g 1 C O}+m_{g 2 C O}+\left(m_{g 1 N O x}+m_{g 2 N O x}\right) \times 6.5, \mathrm{t}
$$

where 6.5 is the conversion factor of $\mathrm{NO}_{\mathrm{x}}$ to $\mathrm{CO}$.

Below is the formula for calculating the mass $m_{d}$ of solid particles (dust) emitted from DGC:

$$
m_{d}=q_{d} \times Q_{r m} \times 10^{-3}, \mathrm{t}
$$

where $q_{d}$ is the specific dust emission from $1 \mathrm{~m}^{3}$ of rock mass, depending on the rock hardness and the explosive formulation: for example, for emulsion explosives at $f=5$ $-6 q_{d}=0.02 \mathrm{~kg} / \mathrm{m}^{3}$; for other dry explosives, the data can be found in the relevant reference literature.

The total mass $M_{\Sigma}$ of harmful substances released during one explosion can be determined by the following formula:

$$
M_{\Sigma}=m_{g 1}+m_{g 2}+m_{d}
$$

The calculation of gross emissions of harmful substances during loading and unloading operations is determined as the sum of harmful substances emitted during the excavation operations, the rock transportation or dumping, and during the engine operation of mining trucks.

The mass $m_{e d 1}$ of dust emitted during the operation of single-bucket excavators is determined by the formula:

$$
m_{e d 1}=q_{s e}\left(3.6 \times \gamma \times E \times \frac{K_{e x}}{t_{c}}\right) \times T_{e x} \times K_{1} \times K_{2} \times 10^{-3},
$$

where $q_{s e}$ is the specific emission of solid particles (dust) from 1 ton of loaded or reloaded material, $\mathrm{g} / \mathrm{t}$;

$\gamma$-rock density, $\mathrm{t} / \mathrm{m}^{3}$;

E-excavator bucket capacity, $\mathrm{m}^{3}$;

$T_{e x}$ - the net operating time of the excavator per year, $\mathrm{h}$;

$K_{e x}$-excavation ratio;

$t_{c}$ - excavator cycle time, $\mathrm{s}$;

$K_{1}$ - coefficient that takes into account the wind speed, $(\mathrm{m} / \mathrm{s})$, and is determined by the most typical value of the wind speed for a given area;

$K_{2}$-coefficient considering material moisture. 
The maximum one-time emission $m_{e s 1}$ of harmful substances during loading operations with a single-bucket excavator is calculated by the Formula (9):

$$
m_{e s 1}=\frac{q_{s e} \times \gamma \times E \times K_{e x} \times K_{1} \times K_{2}}{\left(\frac{1}{3} t_{c}\right)},
$$

Another source of gas and dust emission are bulldozers used for cleaning the top of mineral layers, planning sites, layer-by-layer excavation of rocks and their transportation for a distance of 100-150 m, as well as for work on dumps, etc. The emission of dust and harmful gases into the atmosphere is calculated by the Formulas (10)-(13).

The mass $m_{b m}$ of the dust emitted during the rock excavation or dumping with a bulldozer is determined by the following formula:

$$
m_{b m}=\frac{q_{s e} \times 3.6 \times \gamma \times V \times t_{w t} \times n_{a s} \times 10^{-3} \times K_{1} \times K_{2}}{t_{b c} \times K_{p}}, \mathrm{t} / \text { year }
$$

where $q_{s e}$ is the specific emission of solid particles from 1 ton of transported material, $\mathrm{g} / \mathrm{t}$; $t_{w t}$-net working time of the bulldozer per shift, h;

$V$-the volume of materials dragged by the bulldozer, $\mathrm{m}^{3}$;

$t_{b c}$-cycle time, s;

$n_{a s}$-number of shifts of the bulldozer per year.

The formula for calculating the maximum one-time emission $m_{b e}$ of harmful substances during rock excavation or dumping with a bulldozer is:

$$
m_{b e}=\frac{q_{s e} \times \gamma \times V \times K_{1} \times K_{2}}{t_{b c} \times K_{p}}, \mathrm{~g} / \mathrm{s}
$$

The emission of pollutants from fuel combustion by a bulldozer depends on the mode of its operation. On average, a bulldozer diesel engine runs $40 \%$ of its net shift time at full power, $40 \%$ of the time it uses partial power $(30-40 \%)$ and $20 \%$ of the time it is idle. The mass $m_{\text {beni }}$ of the $i$-th harmful substance emitted during the diesel engine operation of the bulldozer is calculated by the following formula:

$$
m_{\text {beni }}=\left(q_{s e i} \times t_{x x}+q_{s e i} \times t_{40 \%}+q_{s e i} \times t_{100 \%}\right) \times T_{s h} \times N_{b} \times 10^{-3}, \mathrm{t} / \text { year }
$$

where $q_{s e i}$ is the specific emission of the $i$-th harmful substance when the engine is running in the appropriate mode, $\mathrm{kg} / \mathrm{h}$;

$t_{x x}, t_{40 \%}, t_{100 \%}$ are the engine operation time during the shift at the idle speed, with partial use of engine power and at full power, respectively, $\%$.

The total mass $m_{b e n}$ of harmful substances emitted during the operation of the bulldozer engine is determined as follows:

$$
m_{\text {ben }}=\sum m_{\text {beni }}, \mathrm{t} / \text { year }
$$

The mass of sulphur oxides $\mathrm{SO}_{2}$ emitted during the diesel engine operation is determined by the sulphur content in the fuel and in the exhaust gases. The latter is calculated from the measured values of air and fuel consumption.

The calculation of gross emissions of harmful substances during the transportation of rock mass is determined by the mass of gross emissions during fuel combustion in internal combustion engines (e.g., from dump trucks, diesel trolley trucks, diesel locomotives and traction units) and the mass of harmful substances emitted during vehicle traffic.

The mass of the annual emission of harmful substances from fuel combustion in the engines of cars or diesel locomotives is calculated as:

$$
m_{a e}=\sum_{i=t}^{a} m_{a e i}, \mathrm{t} / \mathrm{year}
$$


where $n$ is the total number of impurities released into the atmosphere.

$i$-types of impurities emitted by the source $(i=1 \ldots n)$;

$m_{a e i}$ is the mass of the $i$-th harmful substance emitted during the operation of the truck or diesel locomotive, $\mathrm{t} /$ year and is calculated by:

$$
m_{\text {aei }}=m_{i k} \times n_{\text {days }} \times N_{t r} \times k_{t} \times k_{1} \times 10^{-3},
$$

where $m_{i k}$ is the mass of the $i$-th harmful substance emitted by the engine during the operation in various modes, $\mathrm{kg} /$ day;

$k$-engine operating mode;

$n_{\text {days }}$ - the number of days of machine operation per year;

$N_{t r}$ - the number of working dump trucks or locomotive trains;

$k_{t}$-coefficient of influence of climatic conditions of work;

$k_{1}$-coefficient that depends on the age and technical condition of the trucks.

The mass $m_{i k}$ of the $i$-th harmful substance is determined by the following formula:

$$
m_{i k}=\sum_{k=1}^{3} q_{i k} \times t_{k}, \quad \mathrm{~kg} / \text { day }
$$

where $q_{i k}$ is the specific emission of the $i$-th harmful substance when the engine is operating in the $k$-th mode for engines of diesel locomotives, traction units and for diesel engines of trucks;

$t_{k}$-the engine operation time in $k$-th mode per day, $\mathrm{h}$, which is determined based on the engine operating time in this mode during the run and the total operating time of the machine per day.

The mass $m_{d r}$ of annual dust formation on roads on the vehicles' run is calculated by Formula (17):

$$
m_{d r}=2 \times\left(q_{d r . t} \times K_{5} \times L_{t}+q_{d r . p} \times K_{5} \times L_{p}\right) \times n_{\text {runs }} \times N_{t r} \times 10^{-3}, \quad \mathrm{t} / \text { year }
$$

where $K_{5}$ is a coefficient that takes into account the average speed of dump truck traffic in the open pit mine;

$q_{d r . t}, q_{d r . p}$-the specific dust emission formed when one truck passes $1 \mathrm{~km}$ on temporary and permanent roads, respectively, $\mathrm{kg} / \mathrm{km}$;

$L_{t}, L_{p}$ - the length of temporary and permanent roads, respectively, $\mathrm{km}$;

$n_{\text {runs }}$ - the number of runs of each dump truck per year;

$N_{t r}$-the number of dump trucks in operation.

The mass $m_{d l}$ of solid particles (dust) emitted during all types of loading and unloading operations is determined by the following formula:

$$
m_{d l}=\sum_{t}^{n_{t}} q_{s e} \times Q_{r e} \times K_{1} \times K_{2} \times K_{3} \times K_{4} \times 10^{-6}, \quad \mathrm{t} / \text { year }
$$

where $n_{1}$ is the number of loading and unloading operations of the rock mass;

$K_{3}$-coefficient that takes into account local conditions and the degree of protection of the unit from external influences;

$K_{4}$-coefficient that takes into account the height of unloading of the material;

$q_{s e}$-specific emission of solid particles of the shipped (reloaded) material, $\mathrm{g} / \mathrm{t}$;

$Q_{r e}$ - the annual amount of reloaded or unloaded material, $\mathrm{t} /$ year.

The gross emission of harmful substances (dust) on the overburden dumps is carried out by point, linear and surface sources. Point sources include sites for rock storage, linear sources are transport communications located on the dump, including auxiliary ones, and 
surface sources include dusty dump surfaces. An additional source of air pollution at the dump are mobile sources-trucks and technological trains.

The mass $m_{d o}$ of harmful substances formed on overburden dumps is calculated by Formula (19):

$$
m_{d o}=m_{u . l}+m_{d u} \times S_{d u}+m_{d f} \times S_{d f}, \quad \mathrm{t} / \text { year }
$$

where $m_{u . l}$ is the mass of solid particles emitted in the zone of unloading and laying of rocks, $\mathrm{t}$ /year;

$m_{d u}$-the mass of solid particles blown off from $1 \mathrm{~m}^{2}$ of rocks freshly placed on dump per year, $\mathrm{t} /$ year;

$S_{d u}$-annual area of a freshly placed dump, $\mathrm{m}^{2}$;

$m_{d f}$ - the mass of solid particles blown off from $1 \mathrm{~m}^{2}$ of the deflating surfaces of the dump, t/year;

$S_{d f}$-area of the dump affected by the deflation, $\mathrm{m}^{2}$.

The concentration of emissions in the atmosphere is calculated using the amount of air to ventilate the open pit. The last step is to check whether the emissions do not exceed the maximum permissible concentration (MPC) of harmful substances. If MPC is exceeded, the mining enterprise must develop an action plan to reduce emissions to permissible levels.

The amount of air required to ventilate the open pit using recirculation is $Q_{w}, \mathrm{~m}^{3} / \mathrm{s}$, calculated by the formula:

$$
Q_{w}=K \times h_{c} \times U_{w} \times L,
$$

where $K$ is the coefficient of deceleration of the air flow during the transition to the upper edge of the leeward side;

$L$ - the length of the open pit along the surface in the direction perpendicular to the wind direction, $\mathrm{m}$;

$U_{w}$ - the wind speed, $\mathrm{m} / \mathrm{s}$;

$h_{c}$ - the thickness of the free air jet above the upper edge of the leeward side of the quarry, $\mathrm{m}$.

$$
h_{c}=H\left[\frac{4.6}{(\alpha-20)^{2}+20}+0.046\right] \text {, }
$$

where $\alpha$ is the angle of inclination of the leeward side of the open pit in degrees;

$H$-the pit depth, $\mathrm{m}$.

The concentration of harmful impurities in the atmosphere, $C, \mathrm{mg} / \mathrm{m}^{3}$, is determined by the formula:

$$
C=\frac{\sum J}{Q \times K_{r}}
$$

where $K_{r}$ is a coefficient that takes into account a decrease in the concentration of dust and gas in the upper layers of the atmosphere, usually $K_{r}=0.5-0.8$.

$J$-the volume of emissions of harmful substances, $\mathrm{mg} / \mathrm{sec}$;

3.2.2. Calculation of the Gross Discharges of Harmful Substances into Water Bodies by Mine Transportation Vehicles

To identify the most suitable methodology for calculating the gross discharge of harmful substances into reservoirs from various types of open pit mine transport, an analysis of the methods for assessing the impact on water basin and regulatory documents was conducted. The methodology described in [60] was selected as it most comprehensively reflects the impact of open pit mines on the water basin, and this method was used as a basis for software implementation to calculate the impact of open pit mines on the water basin, including the following parameters:

- the pollution of wastewater provided that the wastewater is discharged into the reservoir from the estimated source with mixing of wastewater from other sources 
and that the concentration of the $i$-th impurity in the wastewater entering the reservoir is not constant during the year;

- the impact of various open pit mine transports on wastewater pollution;

- the pollution due to household needs of mining enterprises;

- the impact of an open pit mine on the water basin based on comprehensive estimation of gross discharges of harmful substances from various types of transport:

- vehicles and motor depots

- railway transport

- conveyor transport

The total mass $M_{W I}$ of the annual discharge into water bodies of the $i$-th impurity is determined depending on the nature of the input into the water body of pollutants from the assessed source. If wastewater is discharged into a reservoir from the assessed source without preliminary mixing with wastewater from other sources, then it is determined by the formula:

$$
M_{W I}=C_{I} \times V_{W},
$$

where $C_{I}$ is the concentration of the $i$-th impurity in the wastewater coming from the source, $\mathrm{g} / \mathrm{m}^{3}$;

$V_{W}$-the annual volume of wastewater discharged by one type of transport into the water management area, million cubic meters $\left(\mathrm{m}^{3} / \mathrm{y}\right)$.

\subsubsection{Calculation of the Negative Impact of an Open Pit Mine on Soil and Subsoil}

The estimation of the impact on soil and subsoil is based on identifying losses and dilution at open pit mines, determined by direct and indirect methods. Direct methods are preferable since they are based on actual measurements of the quantity and quality of ore lost during the production phase and dilution. If direct measurement of the components and types of losses and dilution is possible, they are simply summed up.

Losses of minerals $\eta$ are determined by the expression:

$$
\eta=1-\frac{V_{u} C^{\prime}}{Z C}
$$

where $V_{u}$ is the volume of the extracted mineral from the mineral reserves $Z$;

$\mathrm{C}$ - the content of the useful component in the original mineral ore in the ore mass or in mineral reserves, \%;

$C^{\prime}$ - the content of the useful component in the excavated ore, $\%$.

The ore dilution index $\rho$ is the loss of the quality of the useful mineral during the extraction process, which is determined by the formula:

$$
\rho=\frac{C-C^{\prime}}{C},
$$

In the mining of iron ore deposits, an indicator $\rho^{\prime}$ is used, called the contaminating factor, which is a special case of the dilution factor and is calculated by the formula:

$$
\rho^{\prime}=\frac{V_{d r}}{V_{m r}}
$$

where $V_{d r}$ is the amount of diluting rocks that litter the mineral, $\mathrm{t}$ or $\mathrm{m}^{3}$;

$V_{m r}$-the amount of mined rock mass, $\mathrm{t}$ or $\mathrm{m}^{3}$;

$\rho=\rho^{\prime}$-if the distribution of useful components in the mineral is uniform and the contaminating rocks are waste rock.

The indicators of losses and dilution are interrelated: the lower the dilution the higher the losses, and vice versa. However, the economic effect of reducing losses and dilution is 
usually not the same. It depends on the value of useful components, and the structure and conditions of occurrence of ore deposits. Therefore, when designing an open pit mine a rational level of losses and dilution are determined and planned at which the maximum economic effect and minimum environmental impact could be achieved.

The mathematical model outlined served as a basis for developing a web-based application to track environmental impact assessment for open pit mines.

\section{Results}

\subsection{EIA Web Application Architecture}

The analysis of methods for calculating the impact of mining workings on the subsurface allowed us to develop a software module for open pit mine EIA, identify parameters to be monitored and predicted, as well as methods for software implementation in the '3D Quarry' software.

The result of the research is a development of the software module 'EIA' a part of the web application '3D Quarry' (See Figures 1 and 2).

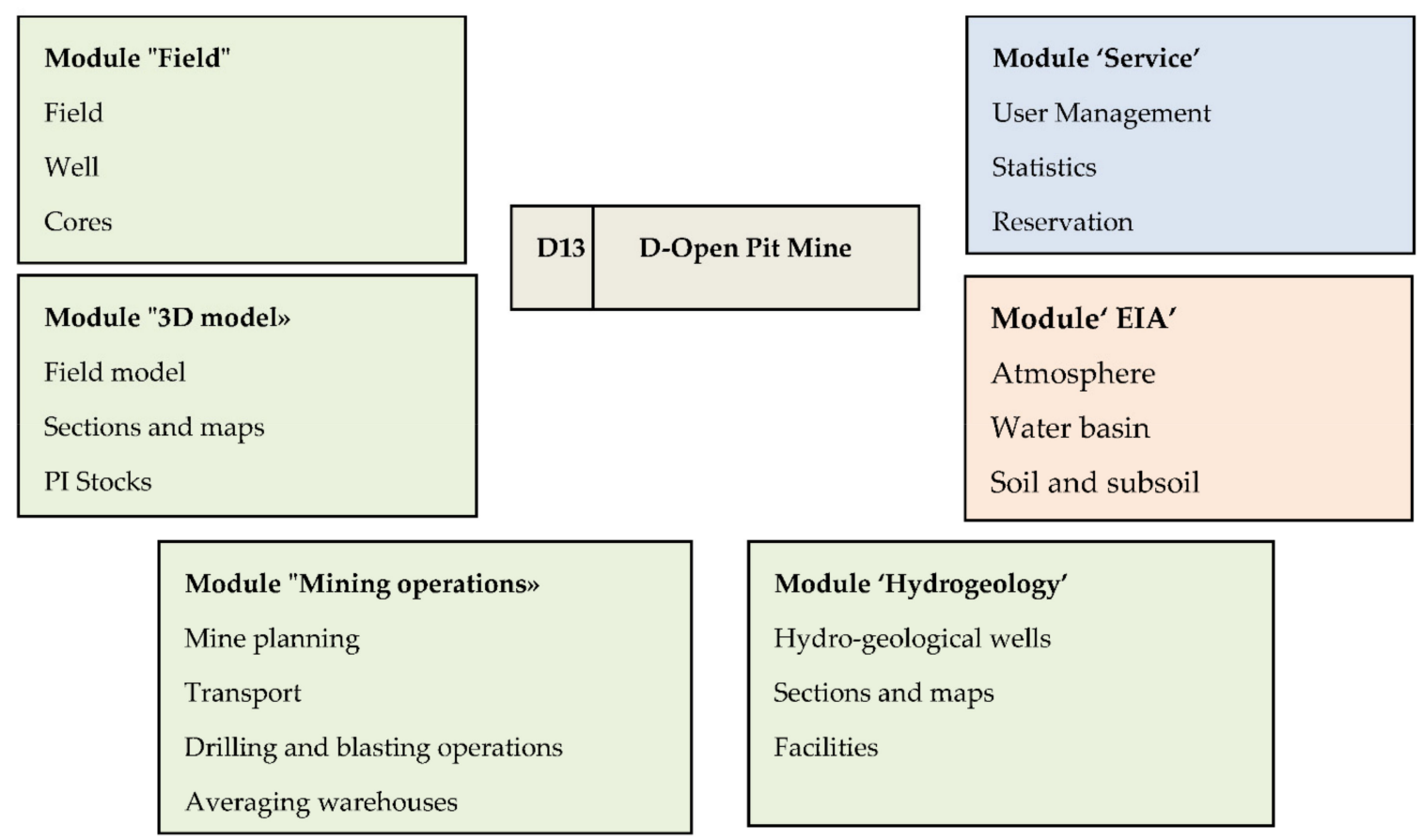

Figure 1. Architecture of the '3D Quarry' system.

Module 'EIA' contains calculations of the impacts on the atmosphere, water basin, soil and subsoil. Calculation of the environmental impact on the atmosphere includes calculation of pollution from drilling operations, pollution blasting operations, pollution from rock load and dumps, pollution from rock mass haulage, and pollution at rock transfer points and dumps. Calculations of the impact on the water basin consists of assessing the impact of drains from the auto transport, drains from the rail transport and drains from the conveyor transport. The impact on the soil and subsoil is assessed by calculating mineral loss and dilution to assist in dump surface planning.

A proposed conceptual solution defines the system as a cloud-based web application, which imposes its own limitations on the development tools of this information system and involves the use of web-based development tools.

Although development tools such as high-level languages allow for developing cloud products, they require significantly more time resources for implementation due to a different orientation. 


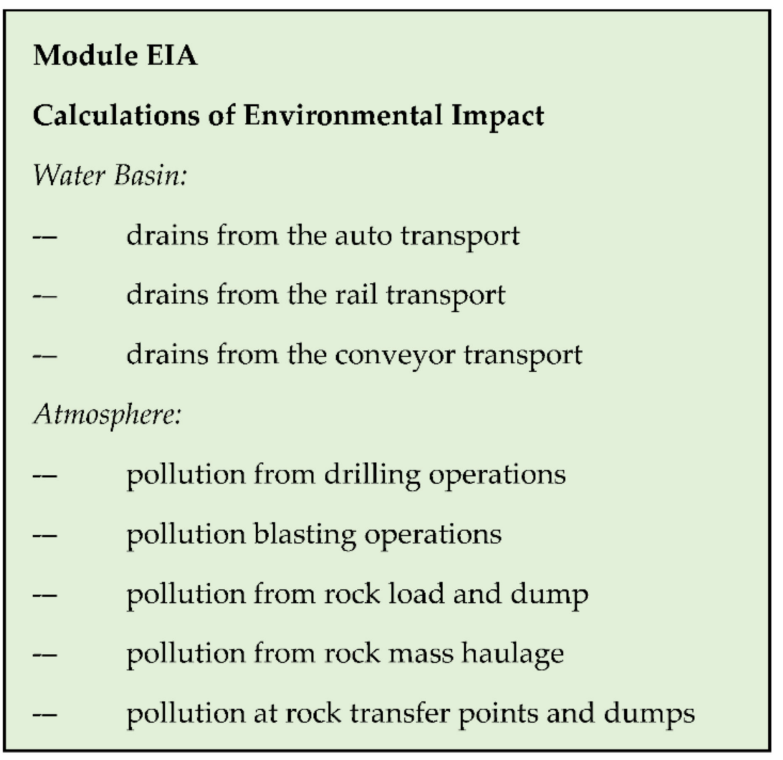

Figure 2. The structure of the 'EIA' module.

The accepted division of the resource functionality into the server side of the interface (back-end) and the client side of the interface (front-end) of the web resource also imposes restrictions on the development tools.

For the implementation of the back-end server, the scripting programming language PHP was used. For the front-end applications, multi-paradigm programming language javascript, javascript framework jQuery and asynchronous data exchange technology Ajax were used.

For the implementation of the database, the analysis of freely distributed web-oriented DBMS was carried out. It was decided to abandon the use of proprietary DBMS for commercial reasons. The analysis of the compliance of the DBMS capabilities allowed to identify and select the MySQL relational DBMS as one of the most common for web projects.

Algorithmically, the methods were implemented using php and javascript programming languages:

- calculation of harmful emissions for the complex of open pit mining equipment (based on specific indicators)

- determination of gross discharges of harmful substances into water bodies by various types of open pit mine transport

- calculation of the negative impact of the open pit mine on the subsoil and land.

\subsection{Cloud Solution Implementation and User Interface Development}

The information system '3D Quarry' has been implemented as a web application [61], and including module 'EIA' was also implemented based on the previously adopted concept:

- the concept of Software as a Service (SaaS) or 'program as a service' for the end user

- data opacity for the resource administrator or storing only data encrypted with the user's personal password in the database

- $\quad$ selectable modularity of the application for the end user

- transparency of the methods used for the end user.

Using the SaaS cloud computing model allows for reducing the cost of software maintenance on the user side by eliminating self-administration of the resource and providing users with ease of operation due to the cross-platform nature of the resource and independence from the hardware and software resources used on the client side. An additional requirement for implementing this approach is the implementation of an adaptive interface (for the screen resolution of the device used by the user). 
Important factors for choosing SaaS as a promotion model included the economic parameters for the resource owner of the '3D Quarry' system: the convenience of controlling the monetisation of the resource, the convenience of protecting against the use of unauthorised copies compared to the Application Service Provider (ASP) concept, and the elaboration of mechanisms for promotion of the resource as a web site. It is anticipated that this decision will help to reduce the share of pirate software copies in the market.

The cyber security aspect is critical for cloud-based software solutions handling highly sensitive data. The opacity of the data for the resource administrator and their storage in the encrypted master key allows the end user to transparently implement the secrecy of his commercial activities. The use of strong encryption algorithms allows the user to protect their data, both from external attacks on the resource and from possible potential attempts to 'pressure' the resource owner to disclose customer information. Symmetric encryption algorithms, such as the Advanced Encryption Standard (AES) algorithm with client-side encryption/decryption and hashing algorithms, MD5 or SHA3, have been applied. The only drawback of this solution is the significant increase in computational load, both on the client's hardware resources and on the communication channel. However, the increased performance of both stationary and mobile computing devices, as well as the widespread introduction of high-speed communication networks, at least based on the LTE standard, allow to successfully address the issues associated with transmitting and processing large amounts of data.

The modular architecture allows to flexibly manage the necessary structure of the resource, build up and upgrade it (including with the possibility of attracting third-party developers), as well as evaluate the contribution of each of the modules to the profitability of the resource, and quite simply and transparently determine the share of the total profit for the developer of each of the modules.

\section{Case Study: The Kurzhunkul Deposit}

The model and parameters of the Kurzhunkul iron ore deposit were used as a demonstration example of automated EIA calculations using the CIA module of the '3D Quarry' system. Due to information confidentiality of the company's activities, the input data used for mine plans was changed.

The mineral deposit is located in the North of the Kostanay region of the Republic of Kazakhstan. The structure of the Kurzhunkul iron ore deposit includes andesites, their tuffs with interlayers of limestones, siltstones (Sarbaiskaya suite); limestones with interlayers of andesites (Sokolovskaya suite); extrusive-blanket formations of quartz porphyries; and subvolcanic formations represented by diorite porphyrites. Dikes composed of diabase porphyrites, rarely spessartites, diorite porphyrites, and granite-porphyries are widely developed. The rocks are hard and very hard, interspersed with unclassified minerals. The hardness of the rocks on the Protodyakonov scale is more than $\mathrm{f}=14$ [62].

The rotary cutter drilling rigs SBSH-250MNA-32 and their Chinese-originated analogues are used in the mining operations. The number of rigs in the field is $\mathrm{N}=5$. The machine productivity experimentally confirmed on the rocks of the Kurzhunkul deposit is about 100 running meters per shift, or approximately 8.33 running meters per hour. The machines work in two shifts. The nominal working hours are 280 days per year. The volumetric productivity of one rig for drilling out the rock from the blast hole is $0.41 \mathrm{~m}^{3} / \mathrm{h}$. The method reference book provides a value of $1.29 \mathrm{~m}^{3} / \mathrm{h}$; however, in the '3D Quarry' application this value is adjusted according to the experimental values obtained for the iron ore deposit under consideration. Such a low productivity of the rigs is due to the operation of the equipment on hard and very hard rocks. The air-water method is used for dust suppression.

The calculated volume of the blasted rock mass is taken on the basis of the experimentally determined value that corresponds to the output of $40 \mathrm{~m}^{3}$ of blasted mass per one running meter of the blast hole and is equal to $5 \times 280 \times 8.33 \times 12 \times 2=11,195,520 \mathrm{~m}^{3} /$ year, which correlates with the actual production volume of $11,000,000 \mathrm{~m}^{3} /$ year. 
The simplest and inexpensive explosives based on ammonium nitrate with the addition of various additives are used at the deposit. Therefore, the most appropriate reference type-ANFO (Ammonium Nitrate/Fuel Oil) - explosives were chosen for the calculations.

In the automated calculation of the EIA module of the system, the input data were taken from the database based on the results of the operation of the modules 'Model' and 'Mine Planning'. The results were obtained through the SQL queries and are summarised in the 'Input data' table (See Figure 3).

$\begin{array}{lll}\text { Field: } & \text { Kurzhunkul } \\ & \text { Coordinates of the center: } & 52^{\circ} 32^{\prime} 25^{\prime \prime} \text { n.l. } \\ 62^{\circ} 42^{\prime} 27^{\prime \prime} \text { e.l. }\end{array}$

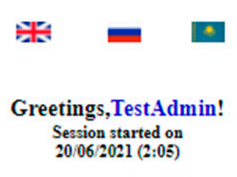

Quit

\begin{tabular}{|c|c|c|c|c|}
\hline \multirow{15}{*}{$\begin{array}{l}\text { Field } \\
\text { Model } \\
\text { Mine planning } \\
\text { CIA } \\
\text { - impact on the } \\
\text { atmosphere: } \\
\text { drilling and imploding } \\
\text { works } \\
\text { loading and unloading } \\
\text { works } \\
\text { transportation of rock } \\
\text { mass } \\
\text { transshipment points } \\
\text { and dumps } \\
\text { - impact on the water } \\
\text { basin: } \\
\text { - impact on subsoil: } \\
\text { - cumulative impact }\end{array}$} & \multicolumn{4}{|c|}{ Calculation of gross emissions of harmful substances during drilling operations } \\
\hline & \multicolumn{4}{|c|}{ Initial data } \\
\hline & Parameter & Unit of measurement & Value & \\
\hline & Hardness of rocks & & f> 14 & Modify value \\
\hline & Drilling rig type & & SBSH-250MNA-32 V & Apply change \\
\hline & Number of drilling rigs & & 5 & \\
\hline & Drilling rig productivity & running meter / hour & 8.33 & Modify value \\
\hline & Volumetric productivity of the drilling rig (Q) & cubic meter / hour & 0.41 & Modify value \\
\hline & Nominal working time fund & days & 280 & Modify value \\
\hline & $\begin{array}{l}\text { The number of shifts per day of operation of drilling } \\
\text { rigs }\end{array}$ & & 2 & Modify value \\
\hline & Nominal fund of machine tools per year $(\mathrm{T})$ & hours & 6720.00 & Modify value \\
\hline & \multirow{2}{*}{ Type of explosive } & & \multirow{2}{*}{ lgdanite $\quad v$} & Apply change \\
\hline & & & & Add new Exp \\
\hline & The volume of the blasted rock mass & $\begin{array}{l}\text { cubic meter / running meter of the } \\
\text { well }\end{array}$ & 40.00 & Modify value \\
\hline & The volume of the blasted rock mass & cubic meter / year & $11,195,520.00$ & \\
\hline
\end{tabular}

Figure 3. Input data for the EIA calculations, generated from the reference data, and the data from the modules 'Deposit', 'Model' and 'Mine Planning'.

The calculation of gross emissions of harmful substances during drilling operations is determined by the mass of dust released during drilling, according to the formulas presented in Section 3.2.1.

Thus, the mass of dust released during well drilling is determined by Formula (1) given in Section 3.2.1:

$$
m_{d m}=\sum_{i=1}^{n} Q_{v p i} \times q_{i} \times T_{i} \times K_{2} \times 10^{-3}=\sum_{i=1}^{5} 0.41 \times 3.5 \times 6720 \times 0.1 \times 10^{-3}=0.48 \mathrm{t} / \text { year }
$$

where $Q_{v p i}=0.41 \mathrm{~m}^{3} / \mathrm{h}$;

$q_{i}=3.5 \mathrm{~kg} / \mathrm{m}^{3}$ (taken for the air-water method of dust collection from the reference handbook for hard rocks);

$T_{i}=2 \times 12 \times 280=6720$, h/year;

$n=5$;

$K_{2}=0.1$ (taken from the reference handbook for hard rocks).

When the dry dust collection method is used, $q_{i}=4.4 \mathrm{~kg} / \mathrm{m}^{3}$ (taken from the reference handbook for hard rocks); and therefore, the value of the mass of dust released during well drilling is equal: 
$m_{d m}=\sum_{i=1}^{n} Q_{v p i} \times q_{i} \times T_{i} \times K_{2} \times 10^{-3}=\sum_{i=1}^{5} 0.41 \times 4.4 \times 6720 \times 0.1 \times 10^{-3}=0.61, \mathrm{t} /$ year

Emergency operation (no dust collection) is prohibited by law. In this mode, the machines could emit 30.42 tons of dust per year.

To ensure flexibility, the interface for the end user provides the ability to manually correct similar data and reference values [63]. The application policy allows the user to create their own database from the base source directories adapted for each specific field.

The user can choose to work with the multiple deposits using the dropdown list. In this case, the user works with only one mine site-the Kurzhunkul field, which was selected for this case study.

The initial data for the EIA calculations are automatically generated by the application based on reference data from the other system modules 'Deposit', 'Model' and 'Production Planning'. The user has rights to manually modify reference data (See Figure 3). To distinguish between different users, the modification of the reference data is applied only for this deposit. This is implemented by creating copies of data directories.

Calculations of emissions to the atmosphere are formed for three methods of dust suppression at once, with the possibility of choosing the optimal mode for the user (See Figure 4).

\begin{tabular}{|c|c|c|c|c|}
\hline \multicolumn{5}{|c|}{ Calculation of gross emissions of harmful substances during drilling operations } \\
\hline & Parameter & Unit of measurement & Value & \\
\hline \multirow{3}{*}{$\begin{array}{l}\text { Specific dust release per } \\
\text { cubic meter of cuttings, } \\
q\end{array}$} & air-water method of dust collection & \multirow{3}{*}{ kilogram / cubic meter } & 3.50 & \multirow{3}{*}{ Modify value } \\
\hline & air method of dust collection & & 4.40 & \\
\hline & no dust collection & & 110.40 & \\
\hline \multicolumn{2}{|c|}{$\begin{array}{l}\text { Coefficient taking into account the moisture content of the } \\
\text { material, } \\
\text { K2 }\end{array}$} & & 0.10 & Modify value \\
\hline \multirow{3}{*}{$\begin{array}{l}\text { Gross dust emission } \\
\text { during drilling, } \\
\text { M1 }\end{array}$} & air-water method of dust collection & \multirow{3}{*}{ tone / year } & 4.40 & \multirow{3}{*}{ Show calc... } \\
\hline & air method of dust collection & & 4.93 & \\
\hline & no dust collection & & 123.65 & \\
\hline
\end{tabular}

Figure 4. A screenshot of the web application page with calculations of the influence of drilling operations.

The results of calculations of the influence of drilling operations are summarised in the table presented in Figure 4. In the system of the '3D Quarry' app, calculations were carried out for three possible modes of dust collection (including emergency). The mode with the minimum dusting is highlighted in green.

The calculation of gross emissions of harmful substances during blasting operations is determined by the mass of harmful substances released during explosions during the year.

The mass of harmful gases is calculated for two main compounds: carbon monoxide and nitrogen oxides, emitted with a dust and gas cloud (DGC).

Formula (2) is used to calculate emissions for carbon monoxide.

$$
m_{g 1}=\sum_{i=1}^{2} q_{g s c i} \times K \times A \times 10^{-6}=2 \times 1.25 \times 9.0 \times 10,075,968 \times 10^{-6}=226.70, \mathrm{t} / \text { year }
$$

where $K=1.25 \mathrm{~g} / \mathrm{L}$ (reference data for ANFO);

$q_{g s c}=9.0 \mathrm{~L} / \mathrm{kg}$ (reference data for ANFO); 
$A=11,195,520 \times 0.9=10,075,968 \mathrm{~kg}$ (based on the volume of the blasted mass and the data on the specific consumption of ANFO equal to $0.9 \mathrm{~kg} / \mathrm{m}^{3}$ for hard rocks, $\mathrm{f}>12$ ).

When calculating emissions for $\mathrm{NO}_{\mathrm{x}}$ gases, the coefficients are

$K=1.4 \mathrm{~g} / \mathrm{L}$ (reference data for ANFO);

$q_{g s c}=4.5 \mathrm{~L} / \mathrm{kg}$ (reference data for ANFO);

The gross emission of $\mathrm{NO}_{x}$ by the Formula (2) is the following:

$$
m_{g 1}=\sum_{i=1}^{2} q_{g s c i} \times K \times A \times 10^{-6}=2 \times 1.4 \times 4.5 \times 10,075,968 \times 10^{-6}=126.95 \mathrm{t} / \text { year }
$$

The concentration of harmful gases remaining in the exploded rock mass (RM) and gradually released into the atmosphere according to Formula (4):

$$
C_{g c i}=\frac{q_{g r i} \times K \times A \times 10^{3}}{Q_{r m}\left(K_{p}-1\right)}
$$

where $q_{g r i}=3.8 \mathrm{mg} / \mathrm{m}^{3}$ (reference data for $\mathrm{CO}$ ) and $q_{g r i}=1.3 \mathrm{mg} / \mathrm{m}^{3}$ (reference data for $\mathrm{NO}_{\mathrm{x}}$ );

$Q_{r m}=11,195,520 \mathrm{~m}^{3}$,

$K_{p}=1.6$ (reference data for hard rocks).

Therefore, the concentration of $\mathrm{CO}$ and $\mathrm{NO}_{\mathrm{x}}$ gases is calculated using the above numbers according to Formula (4):

$$
\begin{aligned}
& \text { for } \mathrm{CO}_{g c i}=\frac{q_{g r i} \times K \times A \times 10^{3}}{Q_{r m}\left(K_{p}-1\right)}=\frac{3.8 \times 1.25 \times 10,075,968 \times 10^{3}}{11,195,520 \cdot(1.6-1)}=7.125 \mathrm{mg} / \mathrm{m}^{3} \\
& \text { for } \mathrm{NO}_{x} C_{g c i}=\frac{q_{g r i} \times K \times A \times 10^{3}}{Q_{r m}\left(K_{p}-1\right)}=\frac{1.3 \times 1.4 \times 10,075,968 \times 10^{3}}{11,195,520 \times(1.6-1)}=2.73 \mathrm{mg} / \mathrm{m}^{3}
\end{aligned}
$$

Then the mass of $\mathrm{CO}$ and $\mathrm{NO}_{x}$ gases is calculated according to Formula (3):

$$
\begin{aligned}
& \text { for } \mathrm{CO} m_{g 2}=\sum_{i=1}^{2} C_{g c i} \times Q_{r m} \times 10^{-9}=2 \times 7.125 \times 11,195,520 \times 10^{-9}=0.16, \mathrm{t} \text {; } \\
& \text { for } \mathrm{NO}_{x} m_{g 2}=\sum_{i=1}^{2} C_{g c i} \times Q_{r m} \times 10^{-9}=2 \times 2.73 \times 11,195,520 \times 10^{-9}=0.061, \mathrm{t} \text {. }
\end{aligned}
$$

The calculation of the total mass of harmful gases released during the explosion (expressed as carbon oxide $\mathrm{CO}$ ) was carried out according to Formula (5);

$m_{g}=m_{g 1 C O}+m_{g 2 C O}+\left(m_{g 1 N O x}+m_{g 2 N O x}\right) \times 6.5=226.7+0.16+(126.95+0.061) \times 6.5=1052.07 \mathrm{t}$

where 6.5 is the conversion factor of $\mathrm{NO}_{\mathrm{x}}$ to $\mathrm{CO}$.

The mass of solid particles (dust) emitted from the DGC is determined by Formula (6), where $q_{d}=0.1 \mathrm{~g} / \mathrm{m}^{3}$ :

$$
m_{d}=q_{d} \times Q_{r m} \times 10^{-3}=0.1 \times 11,195,520 \times 10^{-3}=1119.55 \mathrm{t}
$$

The total mass of harmful substances released during explosions for the year is determined by Formula (7).

$$
M_{\Sigma}=1052.07+1119.55=2171.63 \mathrm{t}
$$


The impact of blasting operations is summarised in the table presented in Figure 5. The total impact of the emitted gases (according to the methodology) is concerted to CO.

\begin{tabular}{|c|c|c|c|c|}
\hline \multicolumn{5}{|c|}{ Calculation of gross emissions of harmful substances during blasting operations } \\
\hline \multicolumn{2}{|l|}{ Parameter } & Unit of measurement & Value & \\
\hline \multirow{5}{*}{$\begin{array}{l}\text { Conversion coefficient for explosive, } \\
\text { K3 }\end{array}$} & $\mathrm{CO}$ & \multirow{3}{*}{ gram / liter } & 1.25 & \multirow[b]{2}{*}{ Modify value } \\
\hline & & & & \\
\hline & NOx & & 1.40 & \\
\hline & $\mathrm{CO}$ & \multirow{2}{*}{ liter / kilogram } & 9.00 & \multirow{2}{*}{ Modify value } \\
\hline & NOx & & 4.50 & \\
\hline \multicolumn{2}{|c|}{ Specific consumption of the selected explosive for the selected rocks } & kilogram / cubic meter & 0.90 & Modify value \\
\hline \multicolumn{2}{|l|}{ Amount of explosives } & kilogram & $10,075,968.01$ & Show calc... \\
\hline \multirow{2}{*}{$\begin{array}{l}\text { The mass of harmful gases emitted with a } \\
\text { dust-gas cloud }\end{array}$} & $\mathrm{CO}$ & \multirow{2}{*}{ kilogram / year } & $226,699.20$ & \multirow{2}{*}{ Show calc... } \\
\hline & $\mathrm{NOx}$ & & $126,951.55$ & \\
\hline \multirow{2}{*}{$\begin{array}{l}\text { Concentration of harmful gas in the } \\
\text { exploded rock mass }\end{array}$} & $\mathrm{CO}$ & \multirow{2}{*}{ milligram / cubic meter } & 3.80 & \multirow{2}{*}{ Modify value } \\
\hline & NOx & & 1.40 & \\
\hline \multirow{2}{*}{$\begin{array}{l}\text { Specific content of harmful gases in the } \\
\text { broken-off rock mass, depending on the } \\
\text { hardness of the rocks and the formulation of } \\
\text { explosives }\end{array}$} & $\mathrm{CO}$ & \multirow[b]{2}{*}{ liter / kilogram } & 3.80 & \multirow[b]{2}{*}{ Modify value } \\
\hline & NOx & & 1.30 & \\
\hline \multicolumn{2}{|l|}{ Loosening coefficient of rock mass } & & 0.90 & Modify value \\
\hline \multirow{2}{*}{$\begin{array}{l}\text { Concentration of harmful gas in the } \\
\text { exploded rock mass }\end{array}$} & $\mathrm{CO}$ & \multirow{2}{*}{ milligram / cubic meter } & 7.13 & \multirow{2}{*}{ Show calc... } \\
\hline & NOx & & 2.73 & \\
\hline \multirow{2}{*}{$\begin{array}{l}\text { The mass of harmful gases remaining in the } \\
\text { exploded rock mass }\end{array}$} & $\mathrm{CO}$ & \multirow{2}{*}{ kilogram / year } & 159.54 & \multirow{2}{*}{ Show calc... } \\
\hline & NOx & & 61.13 & \\
\hline \multicolumn{2}{|l|}{ Conversion coefficient NOx to $\mathrm{CO}$} & & 6.5 & Modify value \\
\hline \multicolumn{2}{|c|}{$\begin{array}{l}\text { The total mass of harmful gases released during the explosion } \\
\text { (reduced to } \mathrm{CO} \text { ) }\end{array}$} & kilogram / year & $1,052,074.65$ & Show calc. \\
\hline \multicolumn{2}{|c|}{$\begin{array}{l}\text { Specific dust release of rock mass depending on rock hardness, } \\
q\end{array}$} & kilogram / cubic meter & 0.10 & Modify value \\
\hline \multicolumn{2}{|c|}{ Mass of solid particles (dust) emitted with a dust-gas cloud } & kilogram / year & $1,119,552.00$ & Show calc... \\
\hline \multicolumn{2}{|c|}{ The total mass of hazardous substances released during explosions } & kilogram / year & $2,171,626.65$ & Show calc... \\
\hline
\end{tabular}

Figure 5. A screenshot of the web application page with calculations of the blasting operations impact.

The difference between the results of the manual and automated methods lies only in the use of units of measurement (tons in the manual and kilograms in the '3D Quarry' system).

Calculations of the impact for all other types of work were performed in a similar way. Summative results are presented in the form of a PDF document (without calculation).

The amount of air used to ventilate the quarry in the recirculation scheme is calculated based on the following values:

$K$-the coefficient of deceleration of the air flow during the transition to the upper edge of the leeward side, $K=0.9$ for the angle of inclination of the side more than $15^{\circ}$; $L=800 \mathrm{~m} ; U_{w}=1.1 \mathrm{~m} / \mathrm{s} ; H=200 \mathrm{~m}$.

The thickness of the free air jet above the upper edge of the leeward wall of the open pit will depend on the angle $\alpha$ (which for the Kurzhunkul open pit was $\alpha=40^{\circ}$ ).

Then the thickness of the jet is calculated by Formula (21) given in Section 3.2.1:

$$
h_{c}=200 \times\left[\frac{4.6}{(40-20)^{2}+20}+0.046\right]=11.39 \mathrm{~m}
$$

The amount of air required to ventilate the open pit using recirculation is calculated by Formula (20)

$$
Q_{w}=0.9 \times 28.48 \times 1.1 \times 800=9021.26 \mathrm{~m}^{3} / \mathrm{s}
$$

For the air-water method of dust collection, the initial concentration of dust in the open pit atmosphere is determined by Formula (22):

$$
C=\frac{4.40 \times 1,000,000 /(3600 \times 24 \times 365)}{9021.26 \times 0.8}=0.019 \mathrm{mg} / \mathrm{m}^{3}
$$


When using the dry dust collection method, the dust concentration in the open pit atmosphere is: $C=0.022 \mathrm{mg} / \mathrm{m}^{3}$.

In the emergency mode of the open pit operation, without dust collection, the dust concentration in the open pit atmosphere is: $C=0.543 \mathrm{mg} / \mathrm{m}^{3}$.

The MPC for dust containing less than $10 \% \mathrm{SiO}_{2}$ is $4 \mathrm{mg} / \mathrm{m}^{3}$. The initial dust concentration in the mode without dust collection exceeds the MPC. Consequently, even despite the liability applied to mining operations without dust collection, there is a need to apply additional dust suppression or collection measures. Both methods of dedusting can achieve an acceptable result.

Formula (22) is also used to determine the initial concentrations of $\mathrm{CO}$ and $\mathrm{NO}_{\mathrm{x}}$ gases. The initial concentration of the $\mathrm{CO}$ gas, $C, \mathrm{mg} / \mathrm{m}^{3}$ is equal to:

$$
C=\frac{(121.5+89.38) \times 1,000,000 /(3600 \times 24 \times 365)}{9021.26 \times 0.8}=0.93 \mathrm{mg} / \mathrm{m}^{3}
$$

The maximum permissible concentration for $\mathrm{CO}$ is $20 \mathrm{mg} / \mathrm{m}^{3}$. The $\mathrm{CO}$ concentration does not exceed the norm.

The initial concentration of $\mathrm{NO}_{\mathrm{X}}$ gas, $\mathrm{C}, \mathrm{mg} / \mathrm{m}^{3}$ is:

$$
C=\frac{(468.04+30.58) \times 1,000,000 /(3600 \times 24 \times 365)}{9021.26 \times 0.8}=0.43 \mathrm{mg} / \mathrm{m}^{3}
$$

The MPC for $\mathrm{NO}_{X}$ is $5 \mathrm{mg} / \mathrm{m}^{3}$. The concentration of $\mathrm{N}_{2} \mathrm{O}_{5}$ does not exceed the norm.

The obtained results show that the maximum permissible concentration of pollutants in the atmosphere is acceptable (see Figure 6), which indicates the effectiveness of natural

\begin{tabular}{|c|c|c|c|}
\hline \multicolumn{4}{|c|}{ Parameters of aerology pit } \\
\hline Parameter & Unit of measurement & Value & \\
\hline $\begin{array}{l}\text { The coefficient of deceleration of the air flow when moving to the } \\
\text { upper edge of the leeward side, } \mathrm{K}\end{array}$ & & 0.90 & Modify value \\
\hline $\begin{array}{l}\text { The size of the pit on the surface in the direction perpendicular to the } \\
\text { wind direction, L }\end{array}$ & meter & $\$ 00.00$ & Modify value \\
\hline Wind speed, $\mathrm{U}$ & meter & 1.10 & Modify value \\
\hline Angle of inclination of the leevard side of the pit, $\alpha$ & degree & 40.00 & Modify value \\
\hline Depth of the pit, $\mathrm{H}$ & meter & 200.00 & Modify value \\
\hline $\begin{array}{l}\text { The thickness of the free air jet above the upper brow of the leeward } \\
\text { side of the pit, } \mathrm{h}\end{array}$ & meter & 11.39 & Show calc... \\
\hline The amount of air used to ventilate the pit, $Q$ & cubic meter / secund & 9021.26 & Show calc... \\
\hline
\end{tabular}
ventilation, with no need for artificial ventilation.

\begin{tabular}{|c|c|c|c|c|}
\hline \multicolumn{5}{|c|}{ Final parameters } \\
\hline \multicolumn{2}{|c|}{ Parameter } & Init of mensirement & Value & \\
\hline \multicolumn{2}{|c|}{$\begin{array}{l}\text { Coefficient that takes into account the decrease in the concentration of dust } \\
\text { and gas in the upper atmosphere }\end{array}$} & & 0.80 & Modif/ value \\
\hline \multicolumn{2}{|c|}{ Maximum permissible concentration for dust } & $\begin{array}{l}\text { milligram / cubic } \\
\text { meter }\end{array}$ & 0.40 & Modif/ value \\
\hline \multirow{3}{*}{ Dust concentration in the atmosphere } & $\begin{array}{l}\text { air-water method of dust } \\
\text { collection }\end{array}$ & \multirow{3}{*}{$\begin{array}{l}\text { milligram / cubic } \\
\text { meter }\end{array}$} & 0.02 & Show calc. \\
\hline & $\begin{array}{l}\text { air method of dust } \\
\text { collection }\end{array}$ & & 0.02 & Show calc... \\
\hline & no dust collection & & 0.54 & Show calc... \\
\hline \multicolumn{2}{|c|}{ Maximum permissible concentration for $\mathrm{CO}$} & $\begin{array}{l}\text { milligram / eubic } \\
\text { meter }\end{array}$ & 20.00 & Modif/ value \\
\hline \multicolumn{2}{|c|}{ Maximum permissible concentration for $\mathrm{NOx}$} & $\begin{array}{l}\text { milligram / cubic } \\
\text { meter }\end{array}$ & 5.00 & Modif/ value \\
\hline \multicolumn{2}{|l|}{$\mathrm{CO}$ concentration in the atmosphere } & $\begin{array}{l}\text { milligram / cubic } \\
\text { meter }\end{array}$ & 0.93 & Show calc... \\
\hline \multicolumn{2}{|l|}{ NOx concentration in the atmosphere } & $\begin{array}{l}\text { milligram / cubic } \\
\text { meter }\end{array}$ & 0.43 & Show calc... \\
\hline
\end{tabular}

Figure 6. Concentration of pollutants in the atmosphere: dust, $\mathrm{CO}$ and NOx. 


\section{Discussion}

The standards, regulatory frameworks and methods for the environmental impact assessment of mining operations vary across counties and geographies [36-52]. This research complements previous studies in discussing methodologies and frameworks for the EIA, pertaining to the country-specific legislative frameworks and industry practices [14-17] in a variety of geographical and mining operation contexts $[18,19]$. The existing research has focused mainly on proposing and discussing the deficiencies of EIA methodologies and models $[14,15,20-23]$.

This research offers a methodology $[59,60]$ as a basis for development of the software module for open pit mining projects. To develop the software module for EIA calculations for open pit mining projects, critical evaluation of existing frameworks and methods for EIA was conducted. As a result, the most suitable methodologies were selected $[59,60]$. In this research, original algorithms for assessing the environmental impact of open pit mining of mineral deposits were developed with reference to the country-specific regulatory frameworks [26-29], adding to the international body of knowledge dedicated to the EIA approaches in the mining industry [14-19,21-25]. The proposed software module enables calculation and reporting of the impacts of mining operations on the surrounding atmosphere, water basin, soil and subsoil.

The example demonstrates the application of the developed software module for the case of the Kurzhunkul iron ore deposit, located in North Kazakhstan.

\section{Conclusions}

This research paper addresses the pressing need for the small open pit mining operators to make environmental impact assessment more accurate and efficient. Based on the critical analysis of the current literature, as well as international and country-specific legislative and regulatory documents for the Environmental Impact Assessment (EIA), a methodological framework was selected and used as a basis for development of a software module to automate calculations of the impact of open pit mines on the environment. The proposed software module is an affordable alternative to commercial off-the-shelf software packages used for mine planning and design, which are often expensive and have functional features that sometimes are not used by small mining enterprises.

The case study demonstrates that the developed algorithms and their implementation in the EIA module are adequate for the selected methods, while integration of the EIA module into the '3D Quarry' system allows for improving the quality of mine planning, assessing environmental risks based on adequate measures to reduce negative impacts.

Calculation and prediction of EIA parameters for open pit mines involve analysis of multiple influencing factors based on sparce and imperfect field datasets. Mathematical methods and models, including correlation analysis, approximation and probabilistic analysis, were used to simulate the missing data points. This significantly increases the cost of calculations and reduces their accuracy.

Future research will be focused on capturing and analysing the dynamics of the inflow of pollutants into the environment, informing the dynamic formation of strategic and tactical measures to reduce the negative impact of open pit mines on the environment.

Author Contributions: Conceptualization, V.Z.; Data curation, M.Z., L.S. and P.S.; Formal analysis, L.S.; Investigation, M.Z. and V.Z.; Methodology, M.Z.; Project administration, L.S.; Resources, O.S.; Software, M.Z.; Supervision, V.Z.; Writing—original draft, M.Z.; Writing—review \& editing, L.S., P.S. and N.M. All authors have read and agreed to the published version of the manuscript.

Funding: This research received no external funding.

Institutional Review Board Statement: Not applicable.

Informed Consent Statement: Not applicable.

Data Availability Statement: Not applicable. 
Conflicts of Interest: The authors declare no conflict of interest.

\section{References}

1. Ghorbani, Y.; Kuan, S.H. A review of sustainable development in the Chilean mining sector: Past, present and future. Int. J. Min. Reclam. Environ. 2017, 31, 137-165. [CrossRef]

2. Franks, D.M.; Boger, D.V.; Côte, C.M.; Mulligan, D.R. Sustainable development principles for the disposal of mining and mineral processing wastes. Resour. Policy 2011, 36, 114-122. [CrossRef]

3. Rashidinejad, F.; Osanloo, M.; Rezai, B. An environmental oriented model for optimum cut off grades in open pit mining projects to minimize acid mine drainage. Int. J. Environ. Sci. Technol. 2008, 5, 183-194. [CrossRef]

4. Zhong, S.; Zhou, L.; Wang, Z. Software for Environmental Impact Assessment of Air Pollution Dispersion Based on ArcGIS. Procedia Environ. Sci. 2011, 10, 2792-2797. [CrossRef]

5. Instructions for Conducting an Environmental Impact Assessment. Order of the Minister of Environmental Protection of the Republic of Kazakhstan No. 204-p of 28 June 2007. Available online: http:/ / adilet.zan.kz/rus/docs/V070004825 (accessed on 14 January 2021).

6. Giurco, D.; Cooper, C. Mining and sustainability: Asking the right questions. Miner. Eng. 2012, 29, 3-12. [CrossRef]

7. Laurence, D. Establishing a sustainable mining operation: An overview. J. Clean. Prod. 2011, 19, 278-284. [CrossRef]

8. Yaylac1, E.D.; Düzgün, H.Ş. Evaluating the mine plan alternatives with respect to bottom-up and top-down sustainability criteria. J. Clean. Prod. 2017, 167, 837-849. [CrossRef]

9. Smirnyakova, V.V. Environmental Impact Assessment of Coal Industry Enterprises, Socio-economic and environmental problems of mining, construction and energy. In A Collection of Scientific Papers of the 9th International Conference on Mining, Construction and Energy; Belarusian National Technical University: Minsk, Republic of Belarus, 2013; pp. 255-259.

10. Mining Industry \& Trends. 2017. Available online: https://sk.kz/upload/iblock/bd6/bd633faf5b911b1371355cf3107b2e27.pdf (accessed on 19 May 2021).

11. Tokayev, K.J. Address of the President of the Republic of Kazakhstan to the Nation of Kazakhstan: Kazakhstan in a New Reality: Time for Action, 1 September 2020, 20202, [Online]. Available online: https://www.akorda.kz/en/addresses/addresses_of_ president/president-of-kazakhstan-kassym-jomart-tokayevs-state-of-the-nation-address-september-1-2020 (accessed on 17 March 2021).

12. Choi, Y.; Baek, J.; Park, S. Review of GIS-Based Applications for Mining: Planning, Operation, and Environmental Management. Appl. Sci. 2020, 10, 2266. [CrossRef]

13. Suh, J.; Kim, S.-M.; Yi, H.; Choi, Y. An Overview of GIS-Based Modeling and Assessment of Mining-Induced Hazards: Soil, Water and Forest. Int. J. Environ. Res. Public Health. 2017, 14, 1463. [CrossRef]

14. Chen, W.; Geng, Y.; Hong, J.; Dong, H.; Cui, X.; Sun, M.; Zhang, Q. Life cycle assessment of gold production in China. J. Clean. Prod. 2018, 179, 143-150. [CrossRef]

15. Yao, K.A.F.; Yao, B.K.; Belcourt, O.; Salze, D.; Lasm, T.; Lopez-Ferber, M.; Junqua, G. Mining Impacts Assessment Using the LCA Methodology: Case Study of Afema Gold Mine in Ivory Coast. Integr. Environ. Assess. Manag. 2020, 17, 465-479. [CrossRef]

16. Lyu, Z.; Chai, J.; Xu, Z.; Qin, Y. Environmental Impact Assessment of Mining Activities on Groundwater: Case Study of Copper Mine in Jiangxi Province, China. J. Hydrol. Eng. 2019, 24, 05018027. [CrossRef]

17. Rahimi, E.; Ghasemzadeh, H. A new algorithm to determine optimum cut-off grades considering technical, economical, environmental and social aspects. Resour. Policy. 2015, 46, 51-63. [CrossRef]

18. Pactwa, K.; Woźniak, J.; Strempski, A. Sustainable mining-Challenge of Polish mines. Resour. Policy 2018. [CrossRef]

19. Ştefănescu, L.; Robu, B.M.; Ozunu, A. Integrated approach of environmental impact and risk assessment of Rosia Montana Mining Area, Romania. Environ. Sci. Pollut. Res. 2013, 20, 7719-7727. [CrossRef]

20. Salom, A.T.; Kivinen, S. Closed and abandoned mines in Namibia: A critical review of environmental impacts and constraints to rehabilitation. S. Afr. Geogr. J. 2020, 102, 389-405. [CrossRef]

21. Global Reporting Initiative (GRI). Available online: https:/ / www.globalreporting.org (accessed on 21 May 2021).

22. Fonseca, A.; McAllister, M.L.; Fitzpatrick, P. Sustainability Reporting among Mining Corporations: A Constructive Critique of the GRI Approach. J. Clean. Prod. 2014, 84, 70-83. [CrossRef]

23. International Standard Organization. Environmental Management: Life Cycle Assessment; Requirements and Guidelines for Organizational Life Cycle Assessment; International Standard Organization: Geneva, Switzerland, 2014; p. 27.

24. Durucan, S.; Korre, A.; Meléndez, G.M. Mining life cycle modelling: A cradle-to-gate approach to environmental management in the minerals industry. J. Clean. Prod. 2006, 14, 1057-1070. [CrossRef]

25. Bojórquez-Tapia, L.A.; Ezcurra, E.; Garcia, O. Appraisal of environmental impacts and mitigation measures through mathematical matrices. J. Environ. Manag. 1998, 53, 91-99. [CrossRef]

26. Rzevsky, V.V. Open Pit Mining. Technology and Overall Mechanisation; Librokom Publishing: Moscow, Russia, $2014 ;$ p. 552.

27. Trubetskoy, K.N.; Potapov, M.G.; Vinnitsky, K.E. Open Pit Mining Manual; Publishing House Gornoe byuro: Moscow, Russia, 1999.

28. Trubetskoy, K.N. The main directions and ways of solving the problems of resource saving in the complex development of mineral resources from the Earth's surface. Min. Inf. Anal. Bull. (Sci. Pract. J.) 2011, 12, 433-446. 
29. Chanturiya, V.A.; Bunin, I.Z. Pulsed power nanotechnologies for disintegration and breaking up of refractory precious metals. In Nanobiotechnology in Energy, Environment and Electronics Methods and Applications; Nicolini, C., Ed.; Pan Stanford Pub: London, UK; New York, NY, USA; Singapore, 2014; pp. 41-66.

30. Ilyin, V.I. Technological Processes and Methods of Industrial Wastewater Treatment; Mendeleev University of Chemical Technology of Russia: Moscow, Russia, 2014; p. 103.

31. Gogina, E.S.; Gurinovich, A.D.; Uretsky, E.A. Resource-Saving Technologies of Industrial Water Supply and Wastewater Disposal; Publishing house of the Association of Civil Engineering Universities: Moscow, Russia, 2012; p. 310. ISBN 978-5-93093-871-5.

32. Pavlova, I.V.; Postnikova, I.N. Protective Materials from Technogenic Pollution (Research Manual); Nizhny Novgorod State Technical University: Novgorod, Russia, 2015; p. 134.

33. Lesin, Y.V.; Lukyanova, S.Y.; Tyulenev, M.A. Mass transfer of dispersed particles during water filtration in macro-grained media. J. Min. Sci. 2010, 46, 78-81. [CrossRef]

34. Lesin, Y.V.; Lukyanova, S.Y. "Wastewater Treatment in Technogenic Rock Massifs", Mining Information and Analytical Bulletin; Publishing House Gornaya Kniga: Moscow, Russia, 2010.

35. Tyulenev, M.A.; Lukyanova, S.Y.; Papin, A.V.; Makarevich, E.A. Transfer of Pollutants During Filtration of Open Pit Wastewater in Overburden; Reports of the Kuzbass State Technical University: Kemerovo, Russia, 2011; pp. 22-30.

36. United States. National Environmental Policy Act of 1969; Pub.L.91-190; 1970; p. 1396. Available online: https://www.epa.gov/ nepa (accessed on 18 June 2021).

37. Eccleston, C.H. NEPA and Environmental Planning: Tools, Techniques, and Approaches for Practitioners; CRC Press: London, UK; New York, NY, USA, 2008; p. 448.

38. Council of the European Economic Community Directive On the assessment environmental impact of selected public and private projects. (85/337/EEC). 1985, p. 47. Available online: https://eur-lex.europa.eu/legal-content/EN/TXT/PDF/?uri=CELEX: 31985L0337\&from $=$ EN (accessed on 18 June 2021).

39. Maksimenko, Y.L.; Cherdantsev, A.P.; Gorkina, I.D. On the Ways of Forming a Regulatory and Methodological Framework for Environmental Impact Assessment During Design. In Environmental Impact Assessment; Practical Experience, Central Russian House of Knowledge: Moscow, Russia, 1992; p. 85.

40. The EU Eco-Management and Audit Scheme (EMAS). Available online: https://ec.europa.eu/environment/emas/index_en.htm (accessed on 6 March 2021).

41. United Nations Economic Commission for Europe (UNECE). Convention on Environmental Impact Assessment in a Transboundary Context; Finland. 1991, p. 37. Available online: https://unece.org/DAM/env/eia/documents/legaltexts/Espoo_Conventio n_authentic_ENG.pdf (accessed on 19 June 2021).

42. ISO 14004 Environmental Management Systems-General Guidelines on Implementation. 2016. Available online: https: / / www.iso.org/standard/60856.html (accessed on 18 May 2021).

43. National Environment Protection Council Act 1994 (NEPC Act). Available online: https://www.legislation.gov.au/Details/C20 16C00844 (accessed on 18 May 2021).

44. South Australia's Environment Protection Act 1993, SA EPA. 1993. Available online: https://www.epa.sa.gov.au/about_us/legis lation (accessed on 18 May 2021).

45. South Australia Mining Act 1971 Version: 25.2.2021. Available online: https://www.legislation.sa.gov.au/lz/c/a/mining\%20ac t\%201971/ current/1971.109.auth.pdf (accessed on 19 June 2021).

46. The Code of the Republic of Kazakhstan On Subsoil and Subsoil Use, 27 December 2017, No 125-VI, (with Amendments and Additions as of 07.03.2021) [Online]. Available online: https://online.zakon.kz/document/?doc_id=31764592 (accessed on 14 March 2021).

47. The Environmental Code of the Republic of Kazakhstan, 9 January 2007, 2007 No. 212-III. (with Amendments and Additions as of 02.01.2021) [Online]. Available online: https:/ / online.zakon.kz/Document/?doc_id=30085593 (accessed on 14 March 2021).

48. The Land Code of the Republic of Kazakhstan No. 442 of June 20, 2003.Updated with Changes on: 01.01.2021 [Online]. Available online: https: / zakon.uchet.kz/rus/docs (accessed on 14 January 2021).

49. The Water Code of the Republic of Kazakhstan No. 481-II of July 9, 2003 (with Amendments and Additions as of 02.01.2021) [Online]. Available online: https:/ / online.zakon.kz/document/ (accessed on 14 January 2021).

50. Standards of the Republic of Kazakhstan ISO 14004:2016. Available online: https:/ / online.zakon.kz/Document/?doc_id=33001 583\#pos=3;-106 (accessed on 6 March 2021).

51. Ratner, S.V.; Almastyan, N.A. Comparing the Efficiency of ISO 14001 and EMAS Environmental Management Systems: A Literature Review. Econ. Anal. Theory Pract. 2016, 7, 106-118.

52. Elyubaev, Z.S. Legal Regulation of Subsoil Use and Investment Activities in the Countries of the Caspian and Black Sea Regions; Conference Development of Upstream in the Caspian and Black Sea Regions: Baku, Azerbaijan, 2014.

53. ESRI GIS Best Practices: Mining, July 2006, G21424. Available online: https://www.esri.com/content/dam/esrisites/sitecore-ar chive/Files/Pdfs/library/bestpractices/mining.pdf (accessed on 6 March 2021).

54. Aquila Drill System. In Caterpillar Performance Handbook, 2012, Edition 41. Available online: https:/ /www.holtcat.com/Docu ments/PDFs / 2012PerformanceHandbook/Technology\%20Products\%20-\%20Sec\%2026.pdf (accessed on 18 May 2021).

55. Caterpillar MineStar team/Mining Software. In International Mining, Hall of Fame. 2018. Available online: https:/ /im-mining. com/site/wp-content/uploads/2020/06/HoF_2018_Software_CaterpillarOL.pdf (accessed on 18 May 2021). 
56. Moore, P. Caterpillar Announces MineStar Edge ${ }^{\mathrm{TM}}$ Mine Management Technology Platform. International Mining. May 2020. Available online: https://im-mining.com/2020/05/12/caterpillar-announces-minestar-edge-mine-management-technologyplatform (accessed on 18 May 2021).

57. Magliulo, P.; Di Lisio, A.; Russo, F. Comparison of GIS-based methodologies for the landslide susceptibility assessment. Geoinformatica 2009, 13, 253-265. [CrossRef]

58. Naghibi, S.A.; Moghaddam, D.D.; Kalantar, B.; Pradhan, B.; Kisi, O. A comparative assessment of GIS-based data mining models and a novel ensemble model in groundwater well potential mapping. J. Hydrol. 2017, 548, 471-483. [CrossRef]

59. Unified Rules on the rational and Integrated Use of Subsoil in the Exploration and Production of Minerals of the Republic of Kazakhstan dated June 15, 2018, No. 239. 2018. Available online: https://www.gosreestr.kz/ru/trade_docs/V1800017131.pdf (accessed on 19 June 2021).

60. Methodology for Determining Gross Discharges of Harmful for the Complex Equipment for Open Pit Mining. A.A. Skochinsky Institute of Mining, Moscow. 1999. Available online: https://files.stroyinf.ru/Data1/59/59758/index.htm (accessed on 18 May 2021).

61. Zarubin, M.; Statsenko, L.; Zarubina, V.; Fionin, E. Developing information systems of operation schedules to stabilize the grade of a mineral. Min. Miner. Depos. 2017, 11, 59-70. [CrossRef]

62. Zarubin, M.Y.; Fionin, E.A.; Danilets, E.V. Analysis of The Qualitative Composition of the Ores of Iron Ore Deposits in Northern Kazakhstan. Geol. Conserv. Miner. Resour. 2013, 2, 28-34.

63. Zarubin, M.; Zarubina, V.; Fionin, E.; Salykov, B.; Salykova, O. Digital System of Quarry Management as a SAAS Solution: Mineral Deposit Module. Min. Miner. Depos. Univ. 2019, 13, 91-102. [CrossRef] 